\title{
Behaviour Change for Sustainable Consumption
}

\section{Wencke Gwozdz ${ }^{1,2} \cdot$ Lucia A. Reisch ${ }^{2} \cdot$ John Thøgersen ${ }^{3}$}

Published online: 4 April 2020

(C) Springer Science+Business Media, LLC, part of Springer Nature 2020

The Paris Agreement goal to limit global warming to $1.5^{\circ} \mathrm{C}$ by 2100 translates into a carbon dioxide $\left(\mathrm{CO}_{2}\right)$ equivalent emission reduction from around 40 gigatons in 2020 to around 5 gigatons (Rockström et al. 2017). As part of a long-term strategy to achieve this goal, technological innovations are necessary, but not sufficient. Another necessary element is changes in consumer and household behaviours, which cannot wait for the long term. In the EU, for example, households account for nearly $20 \%$ of total $\mathrm{CO}_{2}$ emissions (Eurostat 2017). Furthermore, there is a large variation in private households' consumption patterns, which shows that demand-side interventions targeted at private households are indeed promising (Dubois et al. 2019). The largest contributions to $\mathrm{CO}_{2}$ emissions from private households come from personal transport, thermal energy use, electricity consumption, and accommodation as well as consumption of food and consumer goods and services (Kalbar et al. 2016; SteenOlsen and Hertwich 2015). Private households can substantially reduce their $\mathrm{CO}_{2}$ emissions by adopting new or altering the use of in-home and transportation-related technologies or changing consumption patterns related to food and other consumer goods (Gardner and Stern 2008).

This special issue focuses on strategies to induce behaviour changes for sustainable consumption in private households and on key motivational and contextual prerequisites. The aim is to provide insights on instruments and prerequisites for radical behaviour changes, for which the included papers draw on a variety of theoretical and methodological angles and approaches. Content-wise, the papers focus on understanding motivational and contextual facilitators and impediments for changing both specific impactful behaviour and broader behaviour changes. The discussed policy interventions span from a broader policy framework

\section{Lucia A. Reisch}

lre.msc@cbs.dk

\section{Wencke Gwozdz}

wg.msc@cbs.dk

John Thøgersen

jbt@mgmt.au.dk

1 University of Giessen, Giessen, Germany

2 Copenhagen Business School, Frederiksberg, Denmark

3 Aarhus University, Aarhus, Denmark 
for constraining over-consumption to behaviour-specific instruments to produce voluntary behaviour change (de-hassling and eco-labelling).

A key prerequisite for obtaining radical changes towards more sustainable consumption patterns is citizen-consumer support for this goal and at least acceptance of sustainable consumption policy. Two papers in this special issue specifically study antecedents of willingness to change behaviour for sustainable consumption. Koivula et al. (2019) find that ethical consumer orientation is strongly associated with party preferences in Finland, similar to what has previously been documented in the USA and elsewhere (Devinney et al. 2010). However, their study of representative surveys from 1999 to 2014 reveals that an ethical consumer orientation is becoming more mainstream in Finland, party differences in ethical consumer orientation narrowing and converging in the direction of the Greens. Overall, their findings emphasize the importance of understanding how citizens' political preference is embedded in way of life and how deeply it shapes ethical consumption.

Eastman et al. (2019) follow up on the recent upsurge in research on the motivation to act in a sustainable way in specific age groups, but they focus on a somewhat overlooked age group: the seniors. They link the inclination to act sustainably among American seniors to specific personality traits (especially conscientiousness, but also openness and agreeableness) and find that the impact of these three basic dispositions on sustainable behaviour is partially mediated through the seniors' future time perspective (FTP). Their results suggest that communication policies focusing on American seniors' FTP and the three personality traits might be effective tools. On a more general level, the study highlights the role of sometimes overlooked personality variables to encourage sustainable behaviours.

Two papers contribute to research on citizen-consumers' willingness to change or to accept changes in their general lifestyle and consumption patterns to be more sustainable. Rich et al. (2019) develop a validated tool to identify voluntary simplifiers, something that has been severely missed in research on voluntary simplicity. The tool is a 21-item Voluntary Simplicity Engagement Scale with sound psychometric qualities, which is based on the practices of contemporary simplifiers. For developing the scale, they used a mixed-methods approach, combining qualitative interviews with self-identified voluntary simplifiers to identify items and a survey to test the properties of the scale. The scale promises to make future research on voluntary simplicity easier, more integrated, and of higher quality.

Defila and Di Giulio (2020) elevate the discussion of radical lifestyle changes to a more general level, investigating citizen-consumers' acceptance of the concept of "consumption corridors" as a guide for policy. The concept proposes achieving sustainability in consumption by defining minima and maxima levels of consumption. The authors use a representative survey to study how this concept is received in Switzerland. The results suggest a slightly positive openness to endorse the concept, which is related to political attitudes, but the concept is less polarizing than they expected. In general, Swiss citizen-consumers do not reject the concept or find it impossible to put into practice. Hence, it seems that the concept of consumption corridors has the potential to provide common ground for policy-making, beyond traditional political divides.

Four papers discuss interventions to change specific behaviour to become more sustainable, in the areas of home renovation, circular ICT products, fashion, and food products. Many own older houses with a large potential for substantially lowering its energy use through investments in renovating (Dietz et al. 2009), often with a short payback period, but not many homeowners take the initiative (Wilson et al. 2015). De Vries et al. (2019) point at the perceived hassle involved as an important reason why they fail to do this. Homeowners 
perceive hassle during different stages of their journey towards a more energy-efficient home and may even anticipate stress caused by the accumulation of these hassles. Hence, research on the hassle factor as a psychological barrier provides better tools to help homeowners overcome their obstacles and successfully implements policies that facilitate investments in sustainable home improvements. De Vries et al. (2019) suggest de-hassling policy interventions and discuss their effectiveness. Hence, the study contributes to the recent discussion in behavioural public policy on de-hassling and "sludge removal" (Sunstein 2019).

When it comes to buying more sustainable products, such as sustainable food products or circular (i.e., re-used or recycled, or produced with recycled parts or materials (Stangherlin and Thøgersen 2020)) ICT products, the major hassle for consumers is with regard to identifying the sustainable product and (in particular for circular products) assess its quality. Two papers in this special issue — Gåvertsson et al. (2018) and Kuchler et al. (2018) — discuss environmental information and labelling as a means to make it easier for consumers to act on their sustainability intentions and thereby promote sustainable consumer behaviour (Ölander and Thøgersen 2014; Reisch and Thøgersen 2016). Gåvertsson et al. (2018) target consumers' lack of trust in the quality of circular products - one of the biggest impediments for consumer acceptance of these products (Stangherlin and Thøgersen 2020). Based on interviews and a literature review of existing re-use certification initiatives, they propose a label to communicate quality aspects of re-used ICT equipment. However, they find that, in a small country like Sweden, the private sector would not be able to cover the costs of such a labelling scheme alone. Hence, they suggest that a national quality labelling of circular ICT products would require wide stakeholder participation and government support, including being used in public procurement processes.

Labelling has proven a very useful instrument to promote sustainable consumption and especially transform good intentions to action (Thøgersen 2005), but it is not a silver bullet. Kuchler et al. (2018) study the consumer confusion that often impedes the success of environmental communication and labelling. According to prior research, a badly thought through design of the label or communication is a common source of confusion, reducing the impact of the label or information (e.g., Ölander and Thøgersen 2014; Thøgersen and Nielsen 2016). Kuchler et al. (2018) discuss another important confusion factor, namely the (often legal) plethora of broader, more diffuse environmental terms, such as "natural." For example, bio-based products can carry a range of informative labels, such as organic, that certify that the product has met comprehensive regulatory standards. Information about these products also often includes terms with no official definition, such as natural. Research has found that consumers are confused by and often not able to distinguish the meanings of loose terms, such as natural, and well-defined terms, such as USDA Organic on food labels (Kuchler et al. 2017). Based on Google Trends data on the volume of web searches for "organic food" and for "natural food" combined with US-wide data on retail purchases of organic food, Kuchler et al. (2018) find that web searches for both terms predict retail purchases of organic food. This suggests that consumers view the two claims as related, or even identical, and are confused by loosely defined terms. This consumer confusion is potentially detrimental to consumer choices of certified sustainable products.

Finally, McEachern et al. (2020) explore a different path to consumer empowerment with regard to sustainable product choices. They report experiences with more engaging methods, such as interactive upcycling workshops and contemplative theatre performance, to increase consumer awareness of environmental impacts of apparel consumption and bring about behavioural change. Reactions to the experiential methods were positive, initiating much 
reflection and discussion on how participants might modify current behaviour. McEachern et al. (2020) offer a range of suggestions for policymakers and the apparel industry regarding how to encourage consumers to behave more sustainably when buying and disposing of apparel.

In sum, this special issue encompasses general sustainable consumption behaviour as well as specific behaviours such as home renovation, acceptance of circular ICT products, and purchases of sustainable foods and fashion. How to lower well-known barriers such as perceived hassle to perform a sustainable behaviour or a lack of trust in the quality of the products is explored by traditional policy instruments such as labelling as well as more innovative approaches such as interactive upcycling workshops or theatre performance. On a broader level, research on the acceptance of new ideas such as "consumption corridors" delivers promising results. Overall, this special issue contributes to many aspects of existing literature and opens future avenues. One important takeaway is that consumer acceptance and adoption of sustainable behaviour depend on both, lowering the barriers to perform those behaviours as well as finding well-targeted means - whether traditional or creative - to reach consumers. The articles in this special issue show the manifold and creative ways sustainable consumption behaviour can be influenced in order to limit private households' contribution to global warming.

\section{References}

De Vries, G., Rietkerk, M., \& Kooger, R. (2019). The hassle factor as a psychological barrier to a green home. Journal of Consumer Policy. https://doi.org/10.1007/s10603-019-09410-7.

Defila, R., \& Di Giulio, A. (2020). The concept of “consumption corridors" meets society: How an idea for fundamental changes in consumption is received. Journal of Consumer Policy. https://doi.org/10.1007 /s10603-019-09437-w.

Devinney, T. M., Auger, P., \& Eckhardt, G. M. (2010). The myth of the ethical consumer. Cambridge: Cambridge University Press.

Dietz, T., Gardner, G. T., Gilligan, J., Stern, P. C., \& Vandenbergh, M. P. (2009). Household actions can provide a behavioral wedge to rapidly reduce U.S. carbon emissions. Proceedings of the National Academy of Sciences, 106, 18452-18456.

Dubois, G., Sovacool, B., Aall, C., Nilsson, M., Barbier, C., Herrmann, A., Bruyere, S., Andersson, C., Skold, B., Nadaud, F., Dorner, F., Richardsen Moberg, K., Ceron, J. P., Fischer, H., Amelung, D., Baltruszewicz, M., Fischer, J., Benevise, F., Louis, V. R., \& Sauerborn, R. (2019). It starts at home? Climate policies targeting household consumption and behavioral decisions are key to low-carbon futures. Energy Resarch \& Social Science, 52, 144-158.

Eastman, J. K., Modi, P., \& Gordon-Wilson, S. (2019). The impact of future time perspective and personality on the sustainable behaviours of seniors. Journal of Consumer Policy. https://doi.org/10.1007/s10603-01909440-1.

Eurostat. (2017). Greenhouse gas emissions statistics - air emissions accounts. Retrieved from https://ec.europa. eu/eurostat/statistics-explained/index.php/Greenhouse_gas_emission_statistics_-_air_emissions_accounts (accessed 18 Mar 2020).

Gardner, G. T., \& Stern, P. C. (2008). The short list. The most effective actions U.S. households can take to curb climate change. Environment, 50(5), 12-24.

Gåvertsson, I., Milios, L., \& Dalhammar, C. (2018). Quality labelling for re-used ICT equipment to support consumer choice in the circular economy. Journal of Consumer Policy. https://doi.org/10.1007/s10603-0189397-9.

Kalbar, P. P., Birkved, M., Kabins, S., \& Nygaard, S. E. (2016). Personal metabolism (PM) coupled with life cycle assessment (LCA) model: Danish case study. Environment International, 91, 168-179. https://oi. org/10.1016/j.envint.2016.02.032.

Koivula, A., Kukkonen, I., Sivonen, J., \& Räsänen, P. (2019). Is there room for ethical consumers on the Finnish political spectrum? Journal of Consumer Policy. https://doi.org/10.1007/s10603-019-09414-3. 
Kuchler, F., Bowman, M., Sweitzer, M., \& Greene, C. (2018). Evidence from retail food markets that consumers are confused by natural and organic food labels. Journal of Consumer Policy. https://doi.org/10.1007 /s10603-018-9396-x.

Kuchler, F., Greene, C., Bowman, M., Marshall, K.K., Bovay, J., \& Lynch, L. (2017). Beyond nutrition and organic labels - 30 years of experience with intervening in food labels. ERR-239, Washington, DC: U.S. Department of Agriculture, Economic Research Service.

McEachern, M. G., Middleton, D., \& Cassidy, T. (2020). Encouraging sustainable behaviour change via a social practice approach: a focus on apparel consumption practices. Journal of Consumer Policy.

Ölander, F., \& Thøgersen, J. (2014). Informing versus nudging in environmental policy. Journal of Consumer Policy, 37, 341-356. https://doi.org/10.1007/s10603-014-9256-2.

Reisch, L. A., \& Thøgersen, J. (2016). Behaviourally informed consumer policy: research and policy for "humans". In M. Keller, B. Halkier, T.-A. Wilska, \& M. Truninger (Eds.), Routledge handbook on consumption (pp. 294-308). London: Routledge.

Rich, S. A., Wright, B. J., \& Bennett, P. C. (2019). Development of the Voluntary Simplicity Engagement Scale: measuring low-consumption lifestyles. Journal of Consumer Policy. https://doi.org/10.1007/s10603-0189400-5.

Rockström, J., Gaffney, O., Rogelj, J., Meinshausen, M., Nakicenovic, N., \& Schellnhuber, H. J. (2017). A roadmap for rapid decarbonization. Science, 355(6331), 1269-1271. https://doi.org/10.1126/science. aah3443.

Stangherlin, I. d. C., \& Thøgersen, J. (2020). Consumption and materialism: From acquisitive to responsiblematerialism. In T. Tudor \& C. Dutra (Eds.), A handbook of waste, resources and the circular economy (p. forthcoming). London: Routledge.

Steen-Olsen, K., \& Hertwich, E. (2015). Life cycle assessment as a means to identify the most effective action for sustainable consumption. In L. A. Reisch \& J. Thøgersen (Eds.), Handbook of research on sustainable consumption (pp. 131-144). Cheltenham: Edward Elgar Publishing.

Sunstein, C. R. (2019). Sludge and ordeals. Duke Law Review, 68(8), 1843 Retrieved from: https://scholarship. law.duke.edu/dlj/vol68/iss8/6 (accessed 18 Mar 2020).

Thøgersen, J. (2005). Consumer behaviour and the environment: which role for information? In S. Krarup \& C. S. Russell (Eds.), Environment, information and consumer behaviour (pp. 51-63). Cheltenham: Edward Elgar.

Thøgersen, J., \& Nielsen, K. S. (2016). A better carbon footprint label. Journal of Cleaner Production, 125, 86194. https://doi.org/10.1016/j.jclepro.2016.03.098.

Wilson, C., Crane, L., \& Chryssochoidis, G. (2015). Why do homeowners renovate energy efficiently? Contrasting perspectives and implications for policy. Energy Research \& Social Science, 7, 12-22. https://doi.org/10.1016/j.erss.2015.03.002.

Publisher's Note Springer Nature remains neutral with regard to jurisdictional claims in published maps and institutional affiliations. 